\title{
KILKA UWAG KRYTYCZNYCH O USTAWIE O PRAWIE AUTORSKIM I PRAWACH POKREWNYCH Z 1994 R.
}

\section{WPROWADZENIE}

W 2014 r. minęła 20 rocznica uchwalenia ustawy z 4 lutego 1994 r. o prawie autorskim i prawach pokrewnych ${ }^{1}$. Jest to znakomita okazja do podsumowania dotychczasowego dorobku w zakresie ochrony praw autorskich i pokrewnych w Polsce i zastanowienia się nad potrzebą i kierunkami ewentualnych zmian.

Studiując bardzo liczną i obszerną literaturę przedmiotu w zakresie prawa autorskiego można odnieść wrażenie, że regulacja prawa autorskiego w Polsce jest zadowalająca i nie stwarza praktyce większych problemów. Nie jest to pogląd słuszny. Ustawa z $1994 \mathrm{r}$. zawiera braki w regulacji podstawowych kwestii, jak np. brak definicji przedmiotowego zakresu prawa autorskiego, czy też wprowadza dziwną regulację stosunków międzynarodowych. Braki te wynikają częściowo z powielenia w ustawie pr.aut. z 1994 r. przepisów, które zawierała ustawa z 29 marca 1926 r. o prawie autorskim², co oczywiście stwarza wrażenie, że w zakresie ochrony praw autorskich w Polsce czas stanął w miejscu i nadal mamy rok 1926.

Ramy niniejszego opracowania pozwalają na wskazanie jedynie podstawowych problemów. Przedstawione tezy będą raczej głosem w dyskusji niż wskazaniem końcowych rozwiązań.

\section{RYS HISTORYCZNY}

Choć to może wydawać się nieprawdopodobne, Polska przez pewien czas była liderem, jeżeli chodzi o ochronę praw autorskich. Przypomnieć należy, że wydany w 1494 r. przywilej dla Jana Hallera na druk Brewiarza Floriańskiego wyprzedza o kilka lat pierwszy przywilej na druk książki w Niemczech, ojczyźnie Jana Gutenberga, wydany w 1501 r. ${ }^{3}$

1 T.jedn.: Dz. U. 2006, Nr 90, poz. 631 ze zm. (dalej jako: pr.aut. z 1994 r.).

2 Dz. U. Nr 38, poz. 286 (dalej jako: pr.aut. z 1926 r.).

${ }^{3}$ Por. J. Fiołka, Historia Małopolski spisana przez rzecznika patentowego w okazji 40-lecia 
Także pierwsza polska ustawa o prawie autorskim z 1926 r. była ustawa bardzo nowoczesną jak na owe czasy i wprowadzone w niej rozwiąania wyprzedzały ochronę istniejąca wówczas w wielu krajach. Stało się to za sprawa prof. Fryderyka Zolla, który był wybitnym prawnikiem i jednocześnie autorem projektu tej ustawy. Projekt ustawy pr.aut. z 1926 r. prof. Zoll opracował już w 1920 r., a więc prawie zaraz po odzyskaniu przez Polskę niepodległości.

Inne przygotowane przez prof. Zolla projekty ustaw uchwalone przez Sejm 2 sierpnia 1926 r. jako ustawa o prawie właściwym dla stosunków prywatnych międzynarodowych (prawo prywatne międzynarodowe) oraz bliźniacza ustawa o prawie właściwym dla stosunków prywatnych wewnętrznych były nowością na skalę europejska, w owym czasie bowiem żadne z państw europejskich nie uregulowało ustawowo swego prawa prywatnego międzynarodowego w równie szerokim zakresie i w sposób równie nowoczesny jak Polska .

Profesor Zoll tworzył od podstaw ochronę prawa autorskiego w odrodzonej Polsce. Była to wtedy w Polsce swego rodzaju terra incognita. Mimo to była to ustawa bardzo postępowa jak na owe czasy, m.in. bowiem wprowadziła droit moral ${ }^{5}$.

Ustawa z 10 lipca 1952 r. o prawie autorskim ${ }^{6}$ nie dawała powodu do dumy i stanowiła duży regres ochrony prawnoautorskiej w porównaniu z ochrona płynącą z ustawy z 1926 r. Jej główną wadą było to, że zapewniała ona twórcom bardzo niskie wynagrodzenie za korzystanie z ich dzieł oraz krótki okres ochrony, który w przypadku np. utworu fotograficznego, kinematograficznego, przeróbki utworów muzycznych na przyrządy mechaniczne - zgodnie $\mathrm{z}$ art. 27 tej ustawy - wynosił jedynie 10 lat od pierwszej publikacji. Najlepszym przykładem tego stanu rzeczy był fakt, że prawa autorskie do filmu Andrzeja Wajdy Człowiek z marmuru, filmu, którego premiera miała miejsce w 1976 r., a który - jak się powszechnie uważa - w swoim czasie zapoczątkował przemiany ustrojowe, wygasły, zanim nastapiła zmiana ustroju politycznego w Polsce.

Skoro ochrona prawnoautorska do wymienionych utworów wygasała po 10 latach, to każdy w Polsce mógł legalnie rozpowszechniać te utwory, co oczywiście odbywało się kosztem interesów twórców i producentów. Zmusiło to do wprowadzenia w ustawie pr.aut. z 1994 r. przepisu przejściowego - art. 124 ust. 3, zgodnie z którym przepisy tej ustawy „stosuje się do utworów, do których prawa autorskie według przepisów dotychczasowych wygasły, a które

Instytutu Prawa Wtasności UJ, w: A. Matlak, S. Stanisławska-Kloc (red.), Spory o własność intelektualna. Księga jubileuszowa dedykowana Profesorom Januszowi Barcie i Ryszardowi Markiewiczowi, Warszawa 2013, s. 270-271 i cytowana tam literatura.

${ }^{4}$ A. Mączyński, Znaczenie prac Fryderyka Zolla $w$ dziedzinie prawa prywatnego międzynarodowego, w: Fryderyk Zoll 1865-1948. Prawnik-uczony - kodyfikator, Kraków 1994, s. 61 i n.

${ }^{5}$ S. Kosiński, Życie i działalność Fryderyka Zolla, w: Fryderyk Zoll..., s. 14. Pogląd, że ochrona droit moral w Polsce wyprzedziła uregulowania w innych krajach, prezentują S. Serda, Wktad Fryderyka Zolla w rozwój prawa autorskiego, w: Fryderyk Zoll..., s. 52, oraz J. Błeszyński, Le droit d'auteur polonais - traditions et perspectives, „Zeszyty Naukowe Uniwersytetu Jagiellońskiego. Prace z Wynalazczości i Ochrony Własności Intelektualnej” 1988, z. 45, s. 157.

${ }^{6}$ Dz. U. Nr 34, poz. 234 (dalej jako: pr.aut. z 1952 r.). 
według niniejszej ustawy korzystają nadal z ochrony”. Czyli de facto przywrócono ochronę utworów, która pod rządami pr.aut. z 1952 r. wygasła.

Twórcy z powodu niskiego poziomu ochrony płynącej z przepisów pr.aut. z 1952 r. próbowali się powołać na ochronę płynącą z konwencji międzynarodowych w zakresie prawa autorskiego, do których przystapiła Polska. Spowodowało to w literaturze przedmiotu dyskusję na temat, komu w Polsce przysługuje ochrona wynikająca z umów międzynarodowych, których stroną jest Polska, przy czym dyskusja ta dotyczyła całego zakresu ochrony własności intelektualnej, a nie ograniczała się ona tylko do prawa autorskiego. Stanowiska prezentowane w literaturze prawniczej tego okresu uległy polaryzacji. Część badaczy twierdziła, że autorzy krajowi w Polsce nie mogą powołać się na ochronę płynąca z konwencji międzynarodowych, konwencje te bowiem chronia jedynie utwory i prawa autorów zagranicznych ${ }^{7}$. Część z kolei przyjmowała stanowisko, że autorzy krajowi mogą powołać się na ochronę płynąca z konwencji międzynarodowych ${ }^{8}$. Mimo uchwalenia w 1994 r. Konstytucji problem ten pozostaje nadal aktualny. Zgodnie z art. 91 Konstytucji, który stanowi, że „ratyfikowana umowa międzynarodowa, umowa międzynarodowa ratyfikowana za uprzednią zgodą wyrażona w ustawie oraz jeżeli wynika to z ratyfikowanej przez Rzeczpospolitą Polską umowy konstytuującej organizację międzynarodowa, prawo przez nią stanowione jest stosowane bezpośrednio", mając pierwszeństwo w przypadku kolizji z ustawami. Jednakże jeżeli umowy międzynarodowe regulują jedynie prawa autorów zagranicznych, to art. 91 Konstytucji nie zmienia sytuacji autorów krajowych. Dlatego omawiany pogląd uznać należy za całkowicie niesłuszny.

Ustawa o prawie autorskim i prawach pokrewnych z 1994 r. uchwalona została z dużym opóźnieniem, a to za sprawą obstrukcji parlamentarnej Polskiej Partii Przyjaciół Piwa, która została zarejestrowana 28 grudnia 1990 r. przez znanego satyryka Janusza Rewińskiego i Zbigniewa Chomicza i miała być chyba tylko żartem politycznym, który jednak spodobał się wyborcom i posłowie tej partii zostali wybrani do Sejmu. Zasiadajacy w ławach sejmowych przedstawiciele Polskiej Partii Przyjaciół Piwa aktywnie uczestniczyli w pracach komisji sejmowej zajmującej się opracowaniem projektu nowej ustawy o prawie autorskim, głównie popierając przyjęcie poprawek zgłaszanych przez inne osoby. Każda zgłoszona poprawka wymagała osobnego opracowania, rozważenia celowości jej przyjęcia i ewentualnie przeredagowania tekstu pro-

7 Tak A. Kopff, w: Prawo wynalazcze. Zagadnienia wybrane, Warszawa 1978, s. 497; B. Gawlik, Licencje przymusowe w prawie wynalazczym, „Studia Cywilistyczne”, t. 23, 1974, s. 91 i n.; W. Tabor, E. Traple, Konwencja paryska o ochronie własności przemysłowej w świetle tekstu sztokholmskiego, Zeszyty Naukowe Uniwersytetu Jagiellońskiego. Prace z Wynalazczości i Ochrony Własności Intelektualnej, z. 10, Kraków 1977, s. 36; M. Kępiński, Rozporzqdzanie prawem z rejestracji znaku towarowego, Poznań 1979, s. 17; J. Błeszyński, Konwencja berneńska a polskie prawo autorskie, Warszawa 1979, s. 77 i n.; J. Serda, Zagadnienia prawa autorskiego, Warszawa 1973, s. 394 Ostatnio taki sam pogląd prezentuje D. Flisak, w: Prawo autorskie i prawa pokrewne. Komentarz Lex, Warszawa 2015, s. 157-158.

${ }^{8}$ Tak M. Staszków, Instytucje prawa patentowego, Katowice 1972, s. 21-22; S. Sołtysiński, Prawo wynalazcze. Komentarz, Warszawa 1975, s. 94-95; J. Fiołka, Traktaty a prawo wewnętrzne w zakresie ochrony własności intelektualnej, „Zeszyty Naukowe Uniwersytetu Jagiellońskiego. Prace z Wynalazczości i Ochrony Własności Intelektualnej” 1987, z. 44, s. 44 i n. 
jektu ustawy, co oczywiście przeciagało prace ustawodawcze. W efekcie nowa ustawa została uchwalona dopiero po czterech latach od transformacji ustrojowej, chociaż potrzebę zmiany ustawy pr.aut. z 1952 r. dostrzegano od dawna.

Ustawa o pr.aut. z 1994 r. wzorowana jest na ustawie pr.aut. z 1926 r., z której przejęto mniej lub bardziej dosłownie szereg przepisów, nawet nie zmieniając ich numeracji (jak przepisy art. 1, 2, 4, 5), przez co niestety powtórzone zostały błędy zawarte w tej ustawie, pr.aut. z 1994 r. nie wnosi więc wiele nowego do rozwiązania podstawowych problemów ochrony prawnoautorskiej. Ramy niniejszego artykułu, jak już wspomniano, pozwalają na wskazanie tylko niektórych problemów związanych z tą problematyką.

Poza zakresem niniejszego artykułu pozostaje kwestia, czy polska ustawa o prawie autorskim w ogóle jest potrzebna. Obecnie Polska jest członkiem UE, więc ustawodawstwo UE jest częścią polskiego porządku prawnego, a to zgodnie ze wspomnianym art. 91 Konstytucji. Obywatele polscy sa także obywatelami UE, zatem prawo EU stosuje się do nich bezpośrednio.

Problem malejaccego znaczenia prawa krajowego w związku z prawem EU i koniecznością zapewnienia unifikacji rozwiązań prawnych w ramach jednolitego rynku wewnętrznego UE rysuje się ze szczególną ostrością na gruncie prawa patentowego. Omawiając zakres ochrony płynącej z patentu udzielonego przez Urząd Patentowy RP w pracach naukowych powołuje się Protokół do interpretacji art. 69 Konwencji o udzielaniu patentów europejskich $^{9}$, mimo że patenty europejskie udzielane przez Europejski Urząd Patentowy i patenty udzielane przez Urząd Patentowy RP sa niezależne od siebie, a wspomniany Protokół na pewno nie jest częścią ustawy z 30 czerwca 2000 r. ${ }^{10}$ Zauważyć jednak należy, że także Naczelny Sąd Administracyjny poszedł w tym samym kierunku. W orzeczeniu z 21 marca 2012 r. (II GSK 300/11) stwierdził bowiem, że „skoro krajowe przepisy kształtujące przesłanki zdolności patentowej odpowiadają przesłankom określonym w Konwencji z 1973 r. o udzielaniu patentów europejskich, to należy je interpretować w taki sam sposób, zaś ustalając dyrektywy interpretacyjne niezbędne jest uwzględnienie miejsca, jakie zajmuje Konwencja w krajowym porzadku prawnym"11. Orzeczenie to dotyczy kwestii zdolności patentowej wynalaz$\mathrm{ku}$ z zastosowaniem programu komputerowego - w tej materii praktyka Urzędu Patentowego RP negująca całkowicie możliwość uzyskania patentu na takie wynalazki jest archaiczna i znacznie odbiega od praktyki Europejskiego Urzędu Patentowego, którego stanowisko jest dość liberalne w tym względzie.

Dostrzec można wyraźnie pojawiająca się w Polsce tendencję do zanikania znaczenia ustawodawstwa krajowego na rzecz uregulowań międzynarodowych, szczególnie prawa UE, które również w zakresie prawa autorskiego szereg kwestii reguluje bardzo szczegółowo, jak np. ochronę programów komputerowych.

${ }^{9}$ Tak M. du Vall, Prawo patentowe, Warszawa 2008, s. 155, 240; E. Traple, w: R. Skubisz (red.), Prawo własności przemysłowej, Warszawa 2012, s. 762 i n.

${ }_{10}$ T.jedn.: Dz. U. 2003, Nr 119, poz. 1117 ze zm.

${ }^{11}$ Orzeczenie to jest opublikowane w bazie orzeczeń NSA: www.nsa.gov.pl. 


\section{OKREŚLENIE PRZEDMIOTOWEGO ZAKRESU OCHRONY PLYNĄCEJ Z PRAWA AUTORSKIEGO DO UTWORU}

Podstawowym problemem każdego prawa podmiotowego jest określenie jego przedmiotowego zakresu ochrony, mianowicie, jaki jest przedmiot przysługującego prawa. W ustawie pr.aut. z $1994 \mathrm{r}$. kwestię tę regulują niezbyt precyzyjnie art. 1 ust. 1 oraz art. 1 ust. $2^{1}$.

Przepis art. 1 ust. 1 pr.aut. z 1994 r. stanowi, że „przedmiotem prawa autorskiego jest każdy przejaw działalności twórczej o indywidualnym charakterze, ustalony w jakiejkolwiek postaci, niezależnie od wartości, przeznaczenia i sposobu wyrażenia (utwór)”.

Istotną wskazówkę co do przedmiotowego zakresu prawa autorskiego zawiera art. 1 ust. $2^{1}$, który stanowi, że „ochroną objęty może być wyłącznie sposób wyrażenia; nie sa objęte ochroną odkrycia, idee, procedury, metody i zasady działania oraz koncepcje matematyczne”.

Interpretując łacznie te dwa przepisy, stwierdzić należy, że ustawa pr.aut. z 1994 r. chroni jedynie bezpośredni wynik pracy autora. Dozwolone jest poznanie idei zawartej w utworze jakiegoś autora i wykorzystanie tej idei do opracowania własnego utworu. Utwór powstały w oparciu o wykorzystanie idei zawartej w innym utworze nie stanowi naruszenia prawa autorskiego do utworu wcześniejszego, nawet wtedy gdy poznana idea była bardzo oryginalna.

Problem ten najlepiej obrazuje sprawa zmarłego w 1947 r. holenderskiego malarza Hana van Meegerena, który malował obrazy podobne do malarstwa starych holenderskich mistrzów, jednakże miał problemy ze sprzedażą swoich prac. Krytycy uważali prace van Meegerena jedynie za kopie obrazów dawnych mistrzów ${ }^{12}$. Artysta postanowił, że aby udowodnić swój talent, namaluje obraz, który zostanie uznany za autentyczny obraz Jana Vermeera z Delft. W tym celu van Meegeren przez sześć lat badał tematykę obrazów, technikę malowania oraz farby używane przez Vermeera. Farby musiały być przygotowane ręcznie z tych samych surowców naturalnych, których w XVII w. używał Vermeer. Największy problem stanowiły jednak krakelury, drobne pęknięcia na powierzchni płócien starych mistrzów, powstajace wskutek powolnego wysychania farb olejnych. Po wielu nieudanych próbach z piecem elektrycznym do suszenia farb van Meegerenowi udało się uzyskać zadowalający efekt przez dodanie do farb olejnych fenolu i formaldehydu, związków chemicznych nieznanych w czasach Vermeera ${ }^{13}$.

W 1936 r. van Meegeren sprzedał jako dzieło Vermeera namalowany przez siebie obraz Uczniowie w Emaus, za który otrzymał 520 tys. guldenów. Obraz zakupiło kilku nabywców, którzy następnie przekazali go Museum Boijmans w Rotterdamie, gdzie obraz ten stał się jednym z najcenniejszych eksponatów. Żaden z ekspertów malarstwa w Holandii w owym czasie nie wątpił w au-

\footnotetext{
12 Zob. http://pl.wikipedia.org/wiki/Han_van_Meegeren (dostęp: 18.06.2015).

13 Ibidem, podany jest szczegółowy opis wytwarzania farb stosowanych przez Vermeera.
} 
tentyczność tego obrazu, tzn. że jest to rzeczywiście dzieło Vermeera odkryte dopiero w XX w.

Po zakończeniu II wojny światowej w kolekcji obrazów Hermanna Göringa ukrytej w kopalni soli w Austrii alianci odnaleźli inny nieznany obraz Jana Vermeera z Delft: Chrystus i jawnogrzesznica ${ }^{14}$. Obraz ten został zwrócony rządowi holenderskiemu, który przekazał go Museum Boijmans w Rotterdamie, gdzie eksponowano także inne dzieła Vermeera, w tym również Uczniów $w$ Emaus. Autentyczność autorstwa obrazu Chrystus i jawnogrzesznica Vermeera potwierdzili czołowi holenderscy eksperci malarstwa. Odnalezienie nieznanego dzieła Vermeera stało się sensacją w Holandii. Równocześnie intensywnie poszukiwano osoby, która tak wspaniały zabytek malarstwa holenderskiego sprzedała Göringowi, co stanowiło akt kolaboracji z okupantem, za który wówczas groziła surowa kara. Ślady zaprowadziły do van Meegerena, który został uwięziony. Za kolaborację z hitlerowcami groziła mu kara dożywotniego więzienia. W więzieniu van Meegeren ujawnił, że to on namalował ten obraz. Początkowo nie chciano mu uwierzyć. Sązono, że przyznanie się do fałszerstwa jest tylko elementem taktyki procesowej van Meegerena, maksymalną karą za fałszerstwo była bowiem kara tylko dwóch lat więzienia. Celem sprawdzenia prawdziwości twierdzeń van Meegerena prowadzacy przeciw niemu śledztwo zaproponowali, aby namalował on w więzieniu kopię obrazu Chrystus i jawnogrzesznica. Van Meegeren z kolei zaproponował, że może w swojej pracowni namalować następny obraz Vermeera, pod warunkiem że zostana mu dostarczone materiały potrzebne do wytworzenia farb oraz obraz malarza z XVII w., na którym namaluje tę kopię. Po otrzymaniu potrzebnych materiałów namalował obraz - Jezus wśród doktorów (znany także jako Młody Chrystus lub Uczeni w Piśmie), który przez niektórych ekspertów został uznany za oryginalne dzieło Vermeera. Fakt ten przekonał osoby prowadzące postępowanie, że van Meegeren mógł także namalować obraz Chrystus i jawnogrzesznica. Ostatecznie malarz został skazany jedynie za oszustwo polegające na sprzedaży swoich obrazów jako obrazów Vermeera.

Przypadek ten pokazuje, że można tak dalece wykorzystać ideę twórczości i obrazów jakiegoś twórcy, że osoby postronne, nawet eksperci malarstwa, nie będą w stanie odróżnić nowo namalowanego obrazu od obrazów danego mistrza. Jest to zgodne z idea, na której opiera się prawo autorskie, chroni przed rozpowszechnieniem przez osoby trzecie bezpośredniego wyniku pracy danego autora. W związku z tym może się zdarzyć, że różne osoby stworzą taki sam utwór. Najprościej jest przedstawić ten problem na przykładzie fotografii. Jeżeli np. czasopismo chce opublikować fotografię jakiegoś zabytku wykonana przez daną osobę, to powinno uzyskać zgodę autora fotografii na jej publikację. Jeżeli strony nie dojdą do porozumienia, np. z powodów finansowych, to czasopismo to może wysłać swojego fotografa, aby zrobił fotografię danego obiektu, i nie stanowić to będzie naruszenia prawa autorskiego do fotografii wcześniej-

\footnotetext{
14 Ibidem.
} 
szej. Oczywiście nie zawsze jest to możliwe, gdyż może się zdarzyć, że chodzi o fotografię, której po pewnym czasie nie da się już powtórzyć, np. fotografię powodzi lub innego przemijającego zjawiska.

Ten zdawać by się mogło prosty schemat ochrony prawnoautorskiej burzą przepisy o utworach zależnych i utworach inspirowanych. Zgodnie z art. 2 pr.aut. z 1994 r.:

1. Opracowanie cudzego utworu, w szczególności tłumaczenie, przeróbka, adaptacja, jest przedmiotem prawa autorskiego bez uszczerbku dla prawa do utworu pierwotnego.

2. Rozporządzanie i korzystanie z opracowania zależy od zezwolenia twórcy utworu pierwotnego (prawo zależne), chyba że autorskie prawa majątkowe do utworu pierwotnego wygasły. W przypadku baz danych spełniających cechy utworu zezwolenie twórcy jest konieczne także na sporządzenie opracowania.

3. $1-1$

4. Za opracowanie nie uważa się utworu, który powstał w wyniku inspiracji cudzym utworem.

Przepis ten stwarza duże problemy. Nie zawiera on definicji pojęć „opracowanie cudzego utworu” ani „utwór inspirowany”, dlatego trudno stwierdzić w danym przypadku, czy jest to utwór zależny, czy tylko inspirowany. W literaturze nie zauważa się, że zakresy tych pojęć się krzyżuja, a nawet wręcz pokrywaja. „Utwór inspirowany” to przecież nic innego niż „opracowanie cudzego utworu”, co najlepiej widać na przykładzie „przeróbki utworu”, która zgodnie z art. 2 ust. 1 stanowi utwór zależny, a nie utwór inspirowany. Gdyby „utwór inspirowany” nie stanowił „opracowania cudzego utworu”, to byłby to niezależny utwór.

Najlepszą ilustracją pojawiających się tu problemów jest wizyta w Polsce prezydenta USA Geralda Forda, który przyleciał do Polski w lipcu 1975 r. Prezydent Ford skupił się na promowaniu handlu pomiędzy dwoma krajami, na kwestiach podatkowych, współpracy przemysłowej, badaniach naukowych i technologiach ${ }^{15}$.

Zgodnie z informacjami pochodzącymi z niepotwierdzonych źródeł oficjalny tłumacz delegacji amerykańskiej przetłumaczył wygłoszone po wylądowaniu na Okęciu słowa powitania prezydenta w następujący sposób: „Polaki, Prezydent pożąda Was, on chce mieć z Wami stosunki [...]”. Oczywiście prezydent nie przyznawał się do autorstwa tych słów, więc mimo że miało to być tłumaczenie, to jednak był to niezależny utwór niebędący słowami polityka i dlatego prawa do tego „utworu” przysługiwały „tłumaczowi”, który zresztą następnego dnia został odesłany do Stanów.

W literaturze nie dostrzega się, że koncepcja prof. Zolla zawarta w pr.aut. z 1926 r. była niedopracowana. Przepis art. 2 pr.aut. z 1994 r. z niewielkimi zmianami redakcyjnymi został przejęty z pr.aut. z 1926 r. ${ }^{16}$

${ }^{15}$ Zob. http://polish.poland.usembassy.gov/wizyty_prezydenckie.html (dostęp: 18.06.2015).

${ }_{16}$ Nie jest słuszny pogląd E. Traple, w: Prawo autorskie i prawa pokrewne..., s. 47 i n., że art. 2 pr.aut. z 1994 r. wprowadza regulację zbliżoną do art. 3 pr.aut. z 1952 r., pierwowzór art. 3 znajdował się bowiem w art. 2 pr.aut. z 1926 r. 


\section{OKREŚLENIE PRZEDMIOTOWEGO ZAKRESU OCHRONY PLYNĄCEJ Z PRAWA AUTORSKIEGO DO UTWORU - TEZY DO DYSKUSJI}

Określenie przedmiotowego zakresu ochrony utworu płynącej z prawa autorskiego ma podstawowe znaczenie dla egzekwowania ochrony. Sąd, któremu przyjdzie rozstrzygać sprawę o naruszenie praw autorskich do utworu, zazwyczaj powoła biegłego i postawi mu pytanie, czy sporny utwór narusza prawa powoda. Z braku wskazówek w ustawie co do ustalania przedmiotowego zakresu utworu powołany biegły wyda opinię na podstawie własnych przemyśleń na temat przedmiotowego zakresu prawa autorskiego, które oczywiście mogą się różnić od przemyśleń innych ekspertów. Dlatego też dla zapewnienia jednolitości orzecznictwa oraz pewności obrotu gospodarczego bardzo ważne jest uregulowanie w ustawie zasad ustalania przedmiotowego zakresu prawa autorskiego, aby w każdym przypadku podobieństwa dwóch utworów dało się ustalić, czy sa to dwa osobne utwory, czy też mamy do czynienia z jedynym utworem, który został bezprawnie skopiowany.

Jak już wskazano, dwie różne osoby mogą wykonać taki sam utwór samodzielnie i nie będzie to stanowiło naruszenia prawa autorskiego do wcześniej opublikowanego utworu, co w literaturze nazywa się czasami plagiatem albo przypisaniem autorstwa.

Teoretycznie więc określenie przedmiotowego zakresu prawa autorskiego jest proste: utwór stanowi pewną całość, która da się przedstawić graficznie, zawartość utworu ani jego idea nie są chronione. Porównując dwa utwory, stwierdzenie istnienia zmian w utworze późniejszym wyklucza plagiat i powoduje, że mamy do czynienia z nowym utworem, do którego prawa ma inny twórca. Powstaje pytanie, jaka minimalna ilość zmian w utworze, który został później opublikowany, jest wymagana do uznania, że mamy do czynienia z nowym utworem. Czy wystarczy 10\%, 20\%, 50\%, czy może 80\%? Zmiany mają dotyczyć „przejawu działalności twórczej o indywidualnym charakterze”, a ściślej: „sposobu wyrażenia”, gdyż to jest przedmiotem prawa autorskiego zgodnie z art. 1 ust. 1 pr.aut. z 1994 r.

Problem ten łatwo jest przedstawić na przykładzie programów komputerowych. W dużym uproszczeniu program komputerowy to zestaw instrukcji dla komputera w postaci linijek odczytywanych kolejno przez komputer. Czy do uznania programu komputerowego stworzonego przez jednego twórcę za nowy inny program wystarczy na gruncie pr.aut. z 1994 r. stwierdzenie istnienia zmian w każdej linijce programu, w co drugiej linijce, w co trzeciej linijce, czy w co czwartej linijce programu? Informatyk w większości przypadków bez problemu jest w stanie stwierdzić, w jaki sposób osiagnięto konkretny wynik, czyli ustali ideę programu, która przecież nie podlega ochronie przewidzianej w pr.aut. z $1994 \mathrm{r}$.

Nieuregulowanym w przepisach pr.aut. z 1994 r. problemem jest, czy ochrona prawnoautorska utworu obejmuje jedynie cały utwór, czy też także jego poszczególne fragmenty. Chodzi o wykorzystanie w innym utworze jakichś fragmentów innego utworu, np. jednego rozdziału książki albo fragmen- 
tu obrazu, kilku nut z innej piosenki. Na to proste pytanie trudno znaleźć jednoznaczną odpowiedź w pr.aut. z 1994 r. oraz w literaturze prawniczej ${ }^{17}$.

Problem ten ilustruje najlepiej głośny ostatnio przypadek powieści Yakuza. Bliźniacza krew, której nastoletnia autorka duże fragmenty swojej książki zapożyczyła z bloga prowadzonego przez inną osobę. Zgodnie z relacjami zamieszczonymi w prasie codziennej plagiatu nie wykryli pracownicy wydawnictwa Bellona i dopiero po upływie wielu miesięcy od publikacji odkryła go autorka bloga, która sama jednak przyznała, że w powieści dokonano przeróbek tekstu z bloga, zmieniono czasowniki, poprzycinano dialogi, z brunetów zrobiono blondynów ${ }^{18}$. Czy była to działalność dozwolona, czy też naruszenie praw do utworu opublikowanego wcześniej, odpowiedź na to pytanie nie jest jednoznaczna.

Pytanie to jest aktualne szczególnie w zakresie tzw. pop music, gdzie często zdarza się, że jakiś wykonawca wykonuje tzw. cover, czyli wykonuje utwór innego artysty. Najbardziej znanym przypadkiem tego rodzaju problemów jest piosenka My Sweet Lord George'a Harrisona, opublikowana w listopadzie 1970 r. Po rozpadzie zespołu The Beatles był to pierwszy utwór byłego członka tego zespołu, który dotarł na szczyty list przebojów. W 1971 r. był to najlepiej sprzedajacy się singiel w Wielkiej Brytanii ${ }^{19}$. Dało to nawet podstawę do twierdzeń, że Harrison był czarnym koniem zespołu The Beatles.

Mniej więcej miesiąc po premierze tej piosenki pojawiły się pogłoski, że jest ona bardzo podobna do piosenki He’s So Fine, przeboju z 1963 r. dziewczęcego zespołu The Chiffons. Sprawa miała swój epilog w sądzie, gdzie w 1976 r. Harrison został skazany za nieświadomy plagiat wcześniejszej piosenki ${ }^{20}$. Wyrok ten musi budzić wątpliwości, obydwie piosenki różnią się bowiem, i to bardzo, czego najlepszym dowodem jest fakt, że utwór zespołu The Chiffons nie wrócił ponownie na listę przebojów, natomiast piosenka Harrisona cieszy się niesłabnącym powodzeniem. Co więcej, nieco wcześniej nieznacznie różniąca się wcześniejszą wersję piosenki George'a Harrisona My Sweet Lord nagrał Billy Preston, ale jego wykonanie nie odniosło znaczącego sukcesu. Natomiast Harrison miał zapłacić na podstawie tego wyroku kwotę 1,6 mln USD tytułem odszkodowania za naruszenie praw autorskich. Kwota ta została zmniejszona do 587 tys. USD. W czasie trwania procesu powód Bright Tunes Corp. został wykupiony za tę kwotę przez Allena Kleina, adwokata, który reprezentował George'a Harrisona w tym procesie, co sąd uznał za naruszenie przez adwokata etyki zawodowej i dlatego zmniejszył należne odszkodowanie do kwoty, którą ten zapłacił za Bright Tunes Corp.

W art. 1 ust. 1 pr.aut. z 1994 r. nieco zmieniono przesłanki ochrony w porównaniu z art. 1 pr.aut. z 1926 r., mimo że wzorowano się na tym przepisie.

\footnotetext{
${ }_{17}$ Najlepszym tego przykładem jest obszerna rozprawa M. Jankowskiej, Autor i prawo do autorstwa, Warszawa 2011, s. 431 i n., a szczególnie s. 433.

${ }_{18}$ Zob. http://ksiazki.wp.pl/tytul,Chora-na-raka-13-latka-pozyczyla-cudza-powiesc-Wydawnictwo-przeprasza-autorka-chce-pieniedzy, wid,21147, wiadomosc.html, wpis z 4 grudnia $2014 \mathrm{r}$.

${ }_{19}$ Zob. http://en.wikipedia.org/wiki/My_Sweet_Lord; J. C .Self, The "My Sweet Lord"/"He's So Fine" plagiarism Suit, The 910, 1993 (dostęp: 18.06.2015).

${ }^{20}$ United States District Court, S.D. New York in re: Bright Tunes Music Corp. v. Harrisongs Music, Ltd., et al., 420 F.Supp. 177 (1976), No. 71 Civ. 602.
} 
W pr.aut. z 1994 r. przedmiotem prawa autorskiego jest „każdy przejaw działalności twórczej o indywidualnym charakterze”, podczas gdy w art. 1 pr.aut. z 1926 r. przedmiotem prawa autorskiego był „każdy przejaw działalności duchowej, noszący cechę osobistej twórczości”. Definicja opracowana przez prof. Zolla bardziej odpowiada istocie ochrony prawem autorskim i potrzebom praktyki. W pr.aut. z 1994 r. przesłanka „twórczości” nabrała samodzielnego bytu i stała się głównym kryterium przyznania ochrony ${ }^{21}$.

Ustawa pr.aut. z $1994 \mathrm{r}$. nie zawiera definicji twórczości. W praktyce przesłanka twórczości stwarza sądom duże problemy. Tak np. Sąd Apelacyjny w Poznaniu w wyroku z 7 listopada 2007 r. ${ }^{22}$ stwierdził, że „działalność twórcza oznacza, że utwór powinien stanowić rezultat działalności o charakterze kreacyjnym, gdy powstanie subiektywnie nowy wytwór intelektu". We wcześniejszym wyroku z 9 listopada 2006 r. ${ }^{23}$ Sąd Apelacyjny w Poznaniu stwierdził, że nie stanowi utworu w rozumieniu pr.aut. z 1994 r. „efekt działalności wyłącznie rutynowej” albo opracowanie stanowiące „zastosowanie wiedzy technicznej”. Trudno się z tym poglądem zgodzić, gdyż każda działalność z punktu widzenia jednostki jest zarówno rutynowa, jak i twórcza, np. słynne zdanie „Ala ma kota” wymaga zastosowania zasad składni języka polskiego i być może stanowi efekt działalności rutynowej. Przestawienie szyku wyrazów w tym zdaniu, mianowicie „Kota ma Ala”, prowadzi do ujemnych efektów, wręcz trudności ze zrozumieniem wypowiedzi.

Zastosowanie wiedzy technicznej w konkretnym opracowaniu może być bardzo twórcze. Projekt architektoniczny to zastosowanie wiedzy technicznej, a niektóre projekty, jak np. nowa siedziba Wydziału Prawa UAM, to przejaw wybitnej twórczości. Jeżeli jakiś architekt zrealizował wiele dobrych projektów, to dla niego wykonanie kolejnego ciekawego projektu architektonicznego to działalność rutynowa. Dlaczego SA twierdzi, że działalność rutynowa albo zastosowanie wiedzy technicznej wyklucza ochronę prawnoautorską? Trudno zrozumieć przesłanki, którymi kierował się SA w wyroku z 9 listopada 2006 r.

Te dwa cytowane wyżej orzeczenia tego samego Sądu Apelacyjnego w Poznaniu są ze sobą sprzeczne, czego nie dostrzega się w literaturze ${ }^{24}$. Pierwsze odwołuje się do subiektywnej nowości, drugie - do obiektywnej nowości, a to nie jest to samo.

O problemach, jakie stwarza obecna regulacja, najlepiej świadczy fakt, że w literaturze pojawił się pogląd kwestionujący możliwość przyznania ochrony z pr. aut. z 1994 r. ze względu na „niski poziom twórczości”, przy czym do utworów o niskim poziomie twórczości zalicza się m.in. listy, pamiętniki, rysunki techniczne, testy egzaminacyjne, książki kucharskie, rozkłady jazdy, cenniki,

${ }^{21}$ M. Poźniak-Niedzielska, A. Niewęglowski, w: System prawa prywatnego, t. 13: Prawo autorskie, red. J. Barta, Warszawa 2013, s. 9; J. Barta, R. Markiewicz, w: iidem (red.), Prawo autorskie i prawa pokrewne, Warszawa 2011, s. 21 i n.; E. Traple, w: ibidem, s. 48, pkt 2; E. Ferenc-Szydełko, w: eadem (red.), Ustawa o prawie autorskim i prawach pokrewnych. Komentarz, Warszawa 2011, s. 10 i n.

${ }^{22}$ I ACa 800/07, Lex, nr 370747.

${ }^{23}$ I ACa 490/06, Lex, nr 298567.

${ }^{24}$ J. Barta, R. Markiewicz, op. cit., s. 23. 
slogany reklamowe ${ }^{25}$. Z tym poglądem trudno się zgodzić, tym bardziej że jego podstawa prawna jest wątpliwa. Przepis art. 1 nie wyklucza z pojęcia utworu dzieł o „niskim poziomie twórczości”. Ochronie podlegają wszystkie dzieła. Ponadto wszystkie wymienione kategorie dzieł, mające rzekomo posiadać niski poziom twórczości, szczególnie np. rysunki techniczne, testy egzaminacyjne, pamiętniki szczególnie znanych polityków, charakteryzują się zazwyczaj wysokim poziomem twórczości, i to nie tylko subiektywnej, ale i obiektywnej, jak np. dziennik osobistego lekarza i przyjaciela Winstona Churchilla wydany również w Polsce ${ }^{26}$. Nie każdy może opracować test egzaminacyjny czy zrobić rysunek techniczny, wymaga to czasami dużego wysiłku intelektualnego, więc dlaczego tego rodzaju dzieła mają być pozbawione ochrony prawnej?

Obecne uregulowanie przedmiotowego zakresu ochrony w pr.aut. z $1994 \mathrm{r}$. jest sprzeczne z dyrektywa Parlamentu Europejskiego i Rady 2009/24/WE z 23 kwietnia 2009 r. w sprawie ochrony prawnej programów komputerowych $^{27}$. Przedmiot ochrony programu komputerowego reguluje art. 1, który stanowi, że „zgodnie z przepisami niniejszej dyrektywy państwa członkowskie chronia prawem autorskim programy komputerowe w taki sposób, jak dzieła literackie w rozumieniu Konwencji berneńskiej o ochronie dzieł literackich i artystycznych. Do celów niniejszej dyrektywy pojęcie "programy komputerowe« obejmuje ich przygotowawczy materiał projektowy (ust. 1). Ochronie podlega każda forma wyrażenia programu komputerowego. Koncepcje i zasady, na których opierają się wszystkie elementy programu komputerowego, włącznie z tymi, na których opierają się ich interfejsy, nie podlegają ochronie prawa autorskiego na podstawie niniejszej dyrektywy" (ust. 2). Zgodnie z art. 1 ust. 3: „program komputerowy podlega ochronie, jeżeli jest oryginalny w takim rozumieniu, że jest własną intelektualną twórczością jego autora. Żadnych innych kryteriów nie stosuje się przy dokonywaniu jego kwalifikacji do ochrony”.

Prawo autorskie z $1994 \mathrm{r}$. nie jest zgodne z przepisami tej dyrektywy, więc zgodnie z art. 91 Konstytucji, ,jeżeli wynika to z ratyfikowanej przez Rzeczpospolitą Polską umowy konstytuującej organizację międzynarodowa, prawo przez nią stanowione jest stosowane bezpośrednio", mając pierwszeństwo w przypadku kolizji z ustawami. Inaczej mówiąc, regulacja programów komputerowych w pr.aut. z 1994 r. zawarta jest obecnie w dyrektywie 2009/24/WE, zawarty bowiem w art. 74 ust. 1 w związku z art. 1 ust. 1 pr.aut. z 1994 r. wymóg, aby program komputerowy stanowił „przejaw działalności twórczej o indywidualnym charakterze”, szczególnie w sposób, jaki przesłanka twórczości jest interpretowana w literaturze i orzecznictwie sądów polskich, jest sprzeczny z cytowanym wyżej art. 1 ust. 3 dyrektywy i jako taki nie stosuje się. W literaturze przedmiotu nie zwraca się na to uwagi, wręcz nie dostrzega się tego problemu ${ }^{28}$. Skoro programy komputerowe mają być chronione zgod-

${ }_{25}$ Ibidem, s. 29, pkt 23.

${ }_{26}$ M. Lord, Wojna Churchilla 1940-1945, Warszawa 2005.

27 PL L 111/16 Dz. Urz. UE z 5 maja 2009 r. (dalej jako: dyrektywa 2009/24/WE).

28 Por. J. Barta, R. Markiewicz, op. cit., s. 456 i n., którzy powołują nieobowiąująca już dyrektywę 91/250; J. Barta, R. Markiewicz, A. Matlak, w: System, t. 13, s. 1081; K. Gienas, w: E. Ferenc-Szydełko (red.), op. cit., s. 418 i n. 
nie z przepisami tej „dyrektywy, jak dzieła literackie w rozumieniu Konwencji berneńskiej o ochronie dzieł literackich i artystycznych" i maja stanowić „przejaw działalności twórczej o indywidualnym charakterze”, to tym samym dyrektywa ta zmienia sposób ochrony dzieł literackich, mianowicie dzieła literackie mają stanowić również „przejaw działalności twórczej o indywidualnym charakterze".

\section{NIEPOTRZEBNE PRZEPISY ZAWARTE W PR.AUT. Z 1994 R.}

W ustawie pr.aut. z 1994 r. znajdują się niepotrzebne przepisy, z których wymienić należy przede wszystkim artykuły 5, 7 oraz 14 .

Stosowanie do art. 5:

przepisy ustawy stosuje się do utworów:

1) których twórca lub współtwórca jest obywatelem polskim lub

$\left.1^{1}\right)$ których twórca jest obywatelem państwa członkowskiego Unii Europejskiej lub państw członkowskich Europejskiego Porozumienia o Wolnym Handlu (EFTA) - stron umowy o Europejskim Obszarze Gospodarczym, lub

2) które zostały opublikowane po raz pierwszy na terytorium Rzeczypospolitej Polskiej albo równocześnie na tym terytorium i za granica, lub

3) które zostały opublikowane po raz pierwszy w języku polskim, lub

4) które są chronione na podstawie umów międzynarodowych, w zakresie, w jakim ich ochrona wynika z tych umów.

Przepis ten został częściowo powielony z art. 5 ustawy pr.aut. z 1926 r., co - jak wspomniano - jest błędem. W chwili uchwalenia ustawy pr.aut. z 1926 r. nie było jeszcze w Polsce ustawy o prawie międzynarodowym prywatnym. Polska także jeszcze nie przystapiła do Konwencji berneńskiej, co nastapiło w $1934 \mathrm{r} .{ }^{29}$ Przepis art. 5 miał zapewne wypełnić tę lukę i zapewnić ochronę utworów obywateli polskich powstałych przed powstaniem odrodzonego Państwa Polskiego.

W pr.aut. z 1994 r. znajduje się także przepis art. 7, który brzmi:

Art. 7. Jeżeli umowy międzynarodowe, których Rzeczpospolita Polska jest strona, przewidują dalej idącą ochronę, niż to wynika z ustawy, do nieopublikowanych utworów obywateli polskich albo do utworów opublikowanych po raz pierwszy na terytorium Rzeczypospolitej Polskiej lub równocześnie na terytorium Rzeczypospolitej Polskiej albo opublikowanych po raz pierwszy w języku polskim - stosuje się postanowienia tych umów.

Sens i celowość wprowadzenia takiego uregulowania trudno zrozumieć. Z tego przepisu płynie wniosek, że pr.aut. z 1994 r. może ograniczyć ochronę płynąca z umów międzynarodowych. Skoro umowy międzynarodowe przewidują szerszą ochronę, niż to wynika z ustawy pr.aut. z 1994 r., to zgodnie z art. 91 Konstytucji stosuje się umowy międzynarodowe, a nie pr.aut. z 1994 r. Dlaczego przepis art. 7 stanowi, że w takim przypadku postanowienia umów mię-

${ }^{29}$ Ratyfikacja Konwencji berneńskiej przez Polskę nastapiła ustawą z 5 marca 1934 r., Dz. U. R.P. Nr 27, poz. 213. 
dzynarodowych stosuje się tylko do „nieopublikowanych utworów obywateli polskich albo do utworów opublikowanych po raz pierwszy na terytorium Rzeczypospolitej Polskiej lub równocześnie na terytorium Rzeczypospolitej Polskiej albo opublikowanych po raz pierwszy w języku polskim”?

Obecnie przepis art. 5 oraz art. 7 pr.aut. z 1994 r. jest przepisem sprzecznym z art. 46 Prawa prywatnego międzynarodowego, który stanowi, że „powstanie, treść i ustanie prawa własności intelektualnej podlegają prawu państwa, w którym ma miejsce korzystanie z tego prawa (ust. 1). To samo dotyczy rozporządzeń prawem własności intelektualnej oraz do ustalenia pierwszeństwa tych praw (ust. 2). Do ochrony praw własności intelektualnej stosuje się prawo państwa, na podstawie którego dochodzi się ochrony" (ust. 3).

Sprawa ta świadczy o słabości polskiego procesu legislacyjnego. W czasie prac nad projektem pr.aut. z 1994 r. powinno się dostrzec, że art. 5, podobnie jak art. 7, reguluje materię prawa prywatnego międzynarodowego, które reguluje osobna ustawa, więc nie ma sensu stwarzać osobnego uregulowania w prawie autorskim.

W piśmiennictwie z zakresu prawa prywatnego międzynarodowego także nie dostrzega się tego problemu i o specjalnej regulacji zawartej w art. 5 i 7 pr.aut. z 1994 r. w ogóle się nie wspomina, mimo że poszczególne instytucje prawa autorskiego, jak autorskoprawne umowy licencyjne, umowa wydawnicza, umowa o korzystanie z utworu sztuk plastycznych czy umowa o produkcję i rozpowszechnianie utworu audiowizualnego, sa tam szeroko omawiane ${ }^{30}$.

Kilka słów poświęcić należy art. 14 ust. 2 pr.aut. z 1994 r., który stanowi, że „instytucja naukowa może, bez odrębnego wynagrodzenia, korzystać z materiału naukowego zawartego w utworze, o którym mowa w ust. 1, oraz udostępniać ten utwór osobom trzecim, jeżeli to wynika z uzgodnionego przeznaczenia utworu lub zostało postanowione w umowie”.

Przepis ten jest całkowicie sprzeczny z zasadami ochrony wynikajacymi z pr.aut. z 1994 r. Jak już o tym wspominano, idea utworu nie podlega ochronie prawnoautorskiej. Tym bardziej ochronie prawnoautorskiej nie podlega zawartość utworu, a szczególnie „materiał naukowy zawarty w utworze”. Przepis art. 14 ust. 2 stanowi, że instytucja naukowa „może”, czyli ma prawo, korzystać z materiału naukowego zawartego w utworze. Skoro przepis art. 14 ust. 2 stwarza wyjątek dla instytucji naukowej zatrudniajacej pracownika, tzn. że innym podmiotom nie przysługuje prawo korzystania z materiału naukowego zawartego w utworze. Takie rozwiązanie ogranicza swobodę badań naukowych szczególnie w przypadkach, gdy chodzi o opublikowane utwory naukowe. Każdy autor utworu naukowego ma obowiąek należytego wykorzystania literatury przedmiotu, a art. 14 ust. 2 wprowadza ograniczenia w tym zakresie. Dlatego przepis ten powinien być usunięty z ustawy.

dr Janusz Fiotka

adwokat i europejski rzecznik patentowy

janusz@dr-fiolka.com

${ }^{30}$ Por. K. Grzybczyk, Umowy licencyjne i pokrewne, w: System prawa handlowego, t. 9: Międzynarodowe prawo handlowe, red. W. Popiołek, Warszawa 2013, s. 1225-1263. 


\section{SOME CRITICAL REMARKS ON THE ACT ON COPYRIGHT AND RELATED RIGHTS OF 1994}

\section{Sum mary}

The article contains critical remarks regarding copyright law of 1994 and identifies deficiencies of the regulation of basic questions, such as the scope of copyright. The author focuses on the requirements upon which protection of a copyrighted work depends, including in particular, the requirement that every manifestation of a creative activity having individual character be treated as subject to copyright. The functioning of creativity requirement in jurisprudence and legal literature is then criticized as being contrary to Directive 2009/24/EC of the European Parliament and the Council on the protection of computer programs. In the author's opinion the definition of work in copyright law of 1926 was more accurate. He further claims that also the provisions of Articles 5 and 7 copyright law of 1994 are contrary to Article 46 of international private law of 2011 and Article 91 of the Polish Constitution. Consequently, those two articles, as well as Article 14.2 should be deleted from copyright law of 1994. 